Lovat Terence John, Gray Marilyn Marjorie, 'Towards a Proportionist Social Work

Ethics: A Habermasian Perspective', British Journal of Social Work, 38 1100-1114

(2008)

\title{
Towards a Proportionist Social Work Ethics: A Habermasian Perspective
}

\begin{abstract}
In this paper we offer an innovative alternative to the deontological and utilitarian approaches which tend to dominate social work ethics, instead proposing a proportionist ethics drawing on the work of Jürgen Habermas. Flyvberg (1998) claims that Habermas 'distanced himself from phronesis and neoAristotelianism', both of which he is purported to have 'rhetorically ... associated with neoconservatism’ (p. 225) and Varela (1992) places Habermas squarely in the Kantian tradition. In this paper, we present an alternative interpretation of Habermas's ethical stance, which is based on our perception of him as a keen observer of and commentator on modern life, not least about human intersubjective relations and communication, and our practical attempts to deal with the intractable problems of difference in an increasingly pluralistic world. Moreover, we see a form of proportionist thinking in Habermas which suggests a close alignment with Aristotelianism and, indeed, Thomism. For social work, an approach of this sort seems particularly urgent as the field tends increasingly towards, on the one hand, technological, rule bound, deontological frameworks, such as codes of ethics and ethics audits (Reamer, 2001) and, on the other hand, ideologically based ethics of care approaches, both of which tend to stultification and obstruction of the practical action appropriate to the age.
\end{abstract}

Key words: Habermas, proportionism, social work ethics, ethical theory, virtue ethics

\section{Introduction}


Habermas is well described as one of the intellectual architects of our contemporary 'moderately post-scientific age' (Lovat, 2003), which he referred to as a 'postmetaphysical age' (Habermas, 2002). In response to this age, we proffer, Habermas offers a form of proportionist ethics, resting on his dependence on Aristotelian and Thomistic thinking, which impels a way of knowing ethically that is entirely beyond deontological and utilitarian approaches. Thus he offers a new and practical approach that is particularly appropriate to a moderately post-scientific, postmetaphysical age.

While still heavily reliant on science in thought and practice, a 'moderately post-scientific age' is nonetheless acutely aware of the limitations of science in addressing adequately all of life's demands and providing all of its answers. Logically, this will affect the field of ethics among other disciplines, especially in areas where scientific and pseudo-scientific approaches to ethics have been applied in fairly pure fashion. Such approaches have been particularly apparent in bioethics and health care ethics generally, where legal concerns have tended to drive ethical processes towards the highly empirical, watertight and litigious-proof end of the spectrum. As an instance, in extreme cases, the results of hospital ethics committee deliberations have been scored and the final decision determined on the basis of instruments designed by social scientists and validated as empirically sound, a practice that began to be questioned as authentically ethical throughout the 1990s (Moreno, 1991; Wolf, 1991; Waldron, 1992; Bruening et al., 1997). While such processes might be able to be validated scientifically and to safeguard institutions legally, a generation even mildly disenchanted with mechanistic approaches to the big issues in life will be particularly sceptical that all ethical proprieties can be addressed in such a 'decisionist' or cold and calculative way. At the same time, the dispositions 
of empirical science are sufficiently in place in the same generation to ensure that the temptation to return to older prescription and rules based approaches to ethics, which Hughes and Baldwin (2006) refer to as 'principlism', will only ever be succumbed to by an ultra conservative minority.

Hence, we propose a new approach to ethical deliberation and judgement that has potential to satisfy the concerns of both those seeking greater ontological certainty than science can provide, while at the same time preserving sufficient scientific grounding to ensure its contemporary appropriateness. The approach is broadly termed 'proportionism' (Lovat, 2003, 2004). Proportionism is an ethical and moral approach that resonates with the interests of those of us who believe that social work is not well-served by either the heavily empirical approaches of evidence-led practice that have gained increasing prominence in the past quarter century nor by dogmatic postmodern science-denying approaches (Gray and Lovat, 2006). Since proportionism holds promise for a more balanced perspective where social work is both science and art, it is worth considering in light of contemporary debates in the field inter alia about whether social work is an evidence-led, rational-technical enterprise or a practical-moral activity, and whether its values are universal or culturally contingent (Ife, 2000; Parton, 2000; Witkin and Harrison, 2001; Gray and Fook, 2004; Gray, 2005; Gray and Powell, forthcoming; Gray, Coates and Yellow Bird, forthcoming).

\section{Establishing the links between Aristotle, Aquinas and Habermas}

Lovat (1991, 2003, 2004) argues that it is possible to assign contemporary positions relative to ethics and morality more or less along lines established in the classical Hellenistic period of Western philosophy. For instance, Plato’s ethics, which might be 
described as anti-scientific mysticism, could be seen to provide the underpinnings for the stream of thought referred to variously as absolutism, prescriptivism or, more formally, deontology. In its extreme form, this thought posits ethical absolutes, eternal and unchanging, able to be applied in unqualified fashion to any given number of instances. For Plato (1987), standards of morality were fixed in the ideas of the Good, the Just and the Right, standards to which those who wished to live good, just and right lives had to conform. It is an approach where the end can never justify the means. This kind of thinking is reflected in social work in an all too familiar utilization of codes of ethics and professional standards as statements that determine professional behaviour and practice. In modern terms, it could be attributed to the ongoing attempts of people like Rawls (1971) to establish a consolidated theoretical underpinning to ethics per se.

In contrast, Protagoras's ethics (cf. Plato, 1989) would seem to represent an opposite approach which might, therefore, be described as anti-mystical scientism. It would seem to provide philosophical foundations for the stream of thought referred to variously as situationism, consequentialism or, more formally, teleology. This is a stream of thought that denies the validity of the kind of ethical absolutes proposed by Plato. Its reliance is on individual sense perception and empirical judgement. It challenges those who wish to live the good, just and right life to work out what this means for themselves relative to the situation at hand and the consequences of their decisions. The working out is to be done on the basis of the best evidence before them using the soundest empirical means available and forming judgements that spring directly from these means. Unlike the former position, it allows for the end to justify the means. In contemporary theory, Foucault's thought is characteristic of this perspective (Chambon et al., 1999). 
Aristotle's (1985) ethics might then be described as mystical scientism, or perhaps scientific mysticism. As with so much of Aristotle's thought, it provides the practical basis for a compromise though, as will be demonstrated, it should most properly be seen as far more than this. It offers the philosophical basis for the proportionist account of ethical judgement that attempts to balance the demand to attend to absolutes with the need to trust our sense perceptions and personal intuition. For Aristotle, there was a supreme good, eudaemonia, but just how it should be applied in real situations required a particular type of judgement, one which took account of ideals while simultaneously addressing realities (Urmson, 1988). Aristotle's ethics were replete with this sense of 'proportion'. The contemporarily popular school of ethical thought, titled virtue ethics, is based heavily on Aristotle's doctrine of the 'golden mean'. This doctrine proposes that virtue is not an idealized form so much as a practical mean between two extremes. Similarly, the closest Aristotle came to a hard definition of justice was in terms that spoke of 'fairness', understood as 'right proportionality'. Right proportion, therefore, became the basis of an ethics of care, such as is pertinent to the healing and service professions. Care is neither guaranteed by firm adherence to fixed standards nor by following empirical judgements on their own. It is in finding the balance between these two extremes that 'good, just and right' care will be exercised. Standards will always be in play but they must be standards that fit the reality of the situation at hand in order for them to guarantee that it is care, rather than a codified precedent, that is being dispensed. At the same time, guidance by standards ensures that the excesses of an overly empirical approach to determining care are modified by precedent, tradition and some wellworn wisdom from the past. 
Aristotle was the major influence on the thought of the great Muslim scholar, Abu al-Ghazzali, born in 1058 Christian Era. al-Ghazzali (1991) spoke much about knowing as a moral entity and, therefore, the importance of acquiring knowledge but, equally, of the moderation necessary for this acquiring to be of positive benefit to all rather than a means of subjugation of others. Above all, for al-Ghazzali, knowledge was given only so that its necessary concomitant, action, could be informed and welldirected. Knowing on its own was useless; its only usefulness was in impelling benevolent action, in the way of Aristotle’s eudaemonia.

al-Ghazzali would go on to become a source of Aristotelian knowledge for his own and many succeeding generations, granted that Aristotle was almost completely lost in al-Ghazzali's time to all but the Islamic world. Around knowing, al-Ghazzali reformulated Aristotle by promoting an Islamic scholarship that was partly about fixed knowledge from on high (after Plato), partly about experiential knowledge (after Protagoras), but, above all, about a knowledge that conjoined these extremes and issued in practical knowledge and practical action. It was this kind of knowing that was the only authentic knowing before God and was, therefore, the only knowing that could lead to 'happiness', a happiness best described as 'virtue'. Inspired by Aristotle, al-Ghazzali's virtuous Muslim was, above all, one in whom one could place trust that what was said was what would be done.

As al-Ghazzali did within Islam, so Aquinas’s influence within Christianity was to free it from earlier conceptions that the holy life was essentially about withdrawal into isolationist and highly cognitive spirituality divorced from the practicalities of action for good. Like his mentor Aristotle, Aquinas was caught between a highly intellectual tradition —in this case that of Augustine (1972) —and a range of earlier traditions of Christianity and pre-Christianity that continued to 
fascinate him, especially after the work of the Islamic scholars came under his gaze. Rather reminiscent of Plato, Augustine's 'good conscience' was in having one’s mind conform perfectly to the mind of the church. In contrast were those earlier Pre-Nicene traditions of Christianity and much of the Aristotelianism that came to him, largely through al-Ghazzali, which emphasized the deeply personal relationship of individuals with their God as the basis of any morality. Like Aristotle before him, Aquinas not only conjoined these two stances but he elicited a new form of moral knowing in the concept of synderesis, described in the Summa (cf. Aquinas, 1936) as an inborn facility that urged us not only to seek truth but to put it into practice. For Aquinas, knowing truth was knowing-on-the-inside what it meant for oneself and then possessing the commitment to act accordingly. If one did not act accordingly, in the best tradition of the New Testament (cf. I Cor, 13; James, 2; I John, 4), one could not claim to know or understand at all.

Aquinas's work is one of the clearest exemplars of revived Aristotelianism in the Middle Ages. Aristotle's habitual strength of character implied that wisdom was more than the knowing implied by Platonism and more sturdy than the sense experience implied by Sophism. Wisdom was built on virtue which was an inbuilt facility courtesy of natural law, characterized by both rationality and senseexperience, or feeling. It was virtue that allowed the individual to discern what was the right, proper and most compassionate action to effect in the given circumstance. Without virtue, one might enact the proper thing in a rational or legal way but instill injustice, hurt or harm to others because of a lack of sensitivity to the full effects on the individuals concerned. On the other hand, lack of virtue could lead to a compassionate act that nonetheless caused a greater array of harm to a greater number because of a lack of rational thought about its full consequences or the full effects of 
fracturing the precedents of law. It is virtue that steers one through these shoals and so safeguards true ethical soundness, or happiness, in Aristotelian terms. At the end of the day, virtue is a practical action that effects this ethical soundness and happiness. It is insufficient to have right thoughts, or even good communication. One must act for the good if good is to be done.

Such thought seems clearly to be a precursor to the strength of the notion of praxis being the assured outpouring of authentic knowing, such as to be found in Habermas. Habermas's great contribution to modern scholarship is in reviving some of the best of ancient and medieval thought and presenting it in an acceptable form for a modern generation. While Habermas has spent his career known chiefly as a neoMarxist and probably atheist, in his later years his work has turned in obvious fashion to issues related more explicitly to theology, spirituality and the mystical thought that we would maintain was actually never far from his grasp (cf. Martin, 2005). It is much of this that lies now so powerfully behind his contribution to ethics.

Habermas (1972, 1974) challenged the contemporary world to consider the different ways in which we claim to 'know'. Knowing facts and figures-the 'empirical-analytic' — is important, he says, as is the knowing of communication and meaning-making — the 'historical-hermenutic' - but the knowing that most truly marks out human intellectual endeavour and has the capacity to transform self and community is 'critical' or 'self-reflective' knowing. Ultimately, this is a critique of all knowing that renders in a profound knowing of self and issues in praxis, that is, practical action for change. In a word, one cannot come to know in this profound sense, including knowing of self, without being changed. It is through the process of coming to know self, invariably entailing an agonizing struggle, that one gradually strips away the inherited knowledge, the familial and cultural baggage, and the 
ignorance that is so often the source of relational misunderstanding, bigotry, hatred, and violence. For Habermas, this latter was the supreme knowledge that marked a point of having arrived as a human being. In as clear a fashion as ever said in our tradition, ethics is seen to be reliant on a particular form of knowledge, partly cognitive, partly experiential, but supremely practical.

Praxis is the necessary concomitant action that results only from knowing self in this radical way. This is a practical action that makes a difference to whatever it is directed towards. Habermas's practical action is the action of radical, unselfish commitment to a cause, a community or an individual that brings a new force into being. In another place, Habermas $(1984,1987)$ develops his thoughts on praxis in eliciting the notion of 'communicative action'. On the surface, the notion is of global communicative competence. However, at a deeper level, there lies a thesis about effective practical action being the result of the most profound knowing, especially the knowing of self. In a word, the most authentic artefacts of communicative action can only come from the wellspring enshrined in the notion of self-reflectivity, from one who knows who they are, values the integrity of being authentic and commits to the benevolent actions and positive relationships that bear the best fruits of human interactivity. This is Aristotle's eudaemonia and Aristotelian virtue ethics with renewed vigour for a new age.

One of the strengths of Habermas's $(1972,1974)$ epistemology is in its exposure of the limitations of any claims to know that rely on simple hierarchies of truth, such as proposed in deontological regimes. At the same time, it shows up the limitations of an over-reliance on stark scientific methodology and/or intuitionist approaches, such as to be found in teleological schema. In resolving these deficiencies, Habermas proposes a way of knowing that builds on, yet supersedes, 
both deontological and teleological formulations of truth and a process by which understanding might be reached in his communicative rationality and discourse ethics (Hugman, 2005). We maintain that Habermas's ethical approach amounts to a modern version of proportionism.

\section{Habermas and proportionism}

The proposition that Habermasian ethics is proportionist by nature suggests that the critical theory on which it rests is, in turn, resting on the ancient and medieval thoughts of Aristotle and Aquinas respectively. In particular, a Habermasian gloss on the notion of 'right proportion' may allow us to see that deeply embedded within is a theory of truth which does not merely build on, synthesize or complement competing theories, but transcends them to provide a new and superior form of knowledge. Aristotle, Aquinas and Habermas have it in common that this form of knowledge is, ultimately, the only way of knowing the truth. So, we propose the epistemic grounds for a far more fortified proportionist account of ethical theory than we have seen thus far. A proportionist account can work to provide a compromise between two less viable extremes but it offers far more than that merely practical expedient.

If one follows the epistemic line of the Habermasian gloss on Aristotle and Aquinas, it is not merely that the extremes are less viable but that they are less epistemically sustainable as well. While it may be attractive for some to believe in ontological 'givens' and for others to hold to the supremacy of intersubjective understandings, the Habermasian verdict is that neither will deliver the truth. Both will delude and disempower, rendering praxis impossible. Only in 'right proportion', a quest for truth that builds on yet supersedes both of these in its conjoining of 
cognitive apprehension and practical action, can truth be attained. Among other things, this account has the capacity to provide a far stronger philosophical basis for virtue ethics than has been commonly proposed to date.

Inevitably, proportionism is not designed to please advocates of either hardline position, neither the deontologist absolutist nor the teleologically inclined situationist. The absolutist may rail against it for purporting to posit universal determinants that are, in fact, malleable to the situation at hand. The thoroughgoing situationist is equally likely to be disenchanted by a method which, however rigorous the process and clear the result, is liable to modification by an insertion of the apparently mystical. In this sense, a proportionist account will challenge the two most dominant approaches to ethical theory of the past forty years or so.

The value of the proportionist line over and against an unqualified absolutism seems fairly obvious. The former contains a flexibility, a realism and a facility for addressing ethical issues in a contemporary way which the latter lacks. Its value over and against situationism is perhaps a little harder to grasp. Utilitarian positions in general have, after all, held something of a monopoly over the past few decades in their claims to suitability to our new pluralist society. Hence, the popular tendency from the 1960s onwards has been to treat ethics as mere social science, with all the research methodology and consensus seeking stratagems proper to the hard end of social science. This trend has been seen no more clearly than in the phenomenon of the 'Institutional Ethics Committee' (IEC) ${ }^{1}$ to be found especially in and around healthcare institutions. The IEC is a coagulation of stakeholder representatives charged with determining principles of ethical protocol and practical solutions for ethical issues in any given instance of healthcare. The dominant method of

\footnotetext{
${ }^{1}$ For an account of the history and purpose of the IEC, see www.nhmrc.gov.au/ethics/human/conduct/history.htm
} 
establishing these principles and formulating solutions has tended in recent times to be one of investigation, deliberation and democratic resolution. In the modern fairly secular and democratic setting, there tend to be no 'givens' that should be privileged and no stakeholders with more rights of discernment than any other.

As also suggested above, in extreme cases, the results of IEC deliberation have been uploaded to software and the supposed ethical protocol downloaded on a spreadsheet. If this were suitable to the forms of plurality found in Western societies of the 1960s to 1990s, it is questionable how adequate they are today. Contemporary Western societies, with their growing portions of fundamentalist Christianity, significant Islamic and Buddhist populations, and the increasing trend for seeking answers to life's big questions through New Age movements and non-scientific ways of knowing generally, are pluralist in a way which much purebred social science can fail to note or admit. In this new pluralism, there is an apparent distrust of the mundane world of the social scientist, and a strong seeking of positions that take account of a measure of the 'given'. In this sort of pluralist society, hardcore utilitarianism and its ethical strategies require modification, and this modification can easily be seen in the repositioning evident in recent bioethical research across a number of fields (Mitchell et al, 1996; Doukas and Berg, 2001; Robertson, 2001; Miller and Brody, 2002; Zoloth, 2002; Kolbian and Shepherd, 2003; Wendler and Shah, 2003).

While its commitment to scientific methodologies is complete, the proportionist line differs from the out-and-out utilitarian position in its propensity to moderate the scientific 'answer' with the influence of the pre-moral principle, or $a$ priori. In other words, it is comfortable with the anomalous position that, in any ethical dilemma, the way ahead which is signalled by the scientific probe and even 
most measures of commonsense may still not contain the fullness of wisdom. This wisdom might impel an action that defies both science and the prima facie presentations of commonsense. Such anomalies are seen regularly in biomedical moral dilemmas when, for instance, decisions are made to prolong treatment to patients who are clinically beyond hope (Mitchell and Lovat, 1993; Mitchell et al., 1993; Borthwick, 1995). Such anomalies are also central to many of the cutting edge and life challenging debates to be found within areas like the healthcare of HIV patients (Sauer, 2003), organ donation (Koppelman, 2003), cross species technology (Robert and Bayliss, 2003), dementia (Hughes \& Baldwin, 2006), and cultural diversity in healthcare (Myser, 2003).

The value of a proportionist position is best captured when we realize that any ethical decision which runs counter to accepted or popular norms cannot be underestimated in terms of its potential to create tension, fear or recrimination. This can be the case even when the final decision is, from the rational view, clearly for the good. The line of proportionist ethics seems to accept this likely tension and to provide a rationale for understanding it. For a start, proportionism accepts that there are general norms by which the community lives, and that they are important and worth heeding. Nonetheless, it does not hold to the belief that this is all there is to the business of moral theorizing and application. Especially in an age still influenced by scientific thought and method, it provides the methodological underpinnings for an approach that can maintain credibility in such an environment. Consequently, there is a need for the community of ethicists to work progressively, logically and meticulously through the data provided by any case at hand, to scrutinize the evidence, discuss its significance and, having examined all factors, to collaborate on 
working towards the best decision available. Only then, is it right and proper to waive, adjust or modify the general norm that pertains to a particular case.

On the other hand, against the rampant situationism that can ensue from waiving or adjusting time honoured norms, the proportionist's attention to the role of the a priori will caution that not all the solutions to life's problems are to be found at the end of rationality and science. On the contrary, many of the most deeply valued phenomena of human life, such as love, friendship, altruism and valour, are far from the neat products of rationality and science. What is best for the human community may not always conform to the outcome of the cost-benefit analysis, the democratic resolution, nor even to what seems most clearly to be the expedient choice in terms of resource allocation criteria. It may not necessarily conform even to the explicit wishes of a particular patient about his or her treatment options or even to individual rights, however well enshrined in law and custom (Parsi and Egan, 2002). It is always possible that the right ethical choice will defy all of these factors. It is possible that, on the best grounds, ethical decisions may be made which are at odds with the scientific conclusion, these best grounds comprising a value which is judged to be of such an overwhelming order that tampering with it might threaten the very foundations on which human life as we understand it has been built. At the heart of the proportionist quest, lies a balance between the time honoured 'given' and the objectified imperative of the situation at hand. This is precisely the kind of balance of 'goods' that we find at the heart of both Aristotelianism and Thomism, and furthermore in the critical self reflective way of knowing of Habermas. The challenge for social work is to consider the proposition that the inherently best and most 
contemporaneously appropriate ethical position from which practice might proceed is a radically revised form of virtue ethics ${ }^{2}$, the natural product of proportionist thought.

\section{Implications for social work}

Despite constant pressures on social work for precise descriptions of what social workers do, the truth is that all social workers know that the very stuff they deal with—human nature—is inherently a realm of uncertainty and unpredictability. No matter how strong the calls for evidence-led practice, and no matter how large the mass of evidence, it is an inescapable fact that good social work practice will forever rest on the ability of social workers to make sound judgements in unique situations, situations which are the complex amalgam of two individuals-the worker and client—sharing worldviews and experiences so as to address the client's problems in coping with a particular aspect of their life. In such contexts, it is well-nigh impossible to predict the consequences of our actions with any certainty, no matter how sophisticated our decision making frameworks and how valid the evidence.

Neither calculative or scientific reasoning, nor efficient procedures and regulations, can remove the uncertainty of ethical deliberation and its dependence on the skilled and wise judgement of the social worker in the moment. Importantly, virtue ethics wholly emphasizes this aspect of deliberation over and beyond prescribed actions and duty bound obligations. The strength of the social worker lies

\footnotetext{
2 While virtue ethics is probably the most discussed perspective in contemporary moral philosophy [see for example, Statman, D. (ed) (1997) Virtue ethics: A critical reader. Edinburgh University Press and Frankel Paul, Jr, E., Miller, F.D. \& Paul, J. (1998) Virtue and Vice. Cambridge University Press] it has received relatively less attention in social work and the authors are currently further developing this approach following McBeath and Webb’s (2002) earlier work in this area (Lovat \& Gray, forthcoming).
} 
precisely in her ability to understand this complex of factors. This is the benefit of proceeding by the terms of a 'virtue ethics' that 'places emphasis upon judgement, experience, understanding, reflection and (moral) disposition. All of this adds up to what we might call the hermeneutic worker-the worker acting within a reflexiveinterpretive process of self and other' (McBeath and Webb, 2002, p. 1016). In this helping process, the social worker's 'use of self' and 'knowledge of self' is pivotal for it rests on his ability to put aside bias and prejudice so as to truly accept and care for the welfare of the client. This motivation to help or be of service to another requires a moral disposition that can never ensue from 'simple rule-following' or 'the mechanical application of rights-claims' (McBeath \& Webb, 2002, p. 1018). As McBeath and Webb (2002) note, virtues, rather than being intrinsic or fixed qualities, develop through training and experience and thus inhere in practice. 'The practice of virtue developed through experience, reflection and circumspection-is the very stuff of good social work' (p. 1020 emphasis added). In the constant flux of the ebb and flow of human life, perfection is impossible but good actions done with the best of intentions are the most likely to produce good outcomes. As Aristotelian ethics shows:

... (the intended) result does not make the actor moral ... The goodness of an action lies in persons in a context of moral appraisal and their motivations and dispositions in the execution and aims of their actions .... this requires scrutiny of the making of the inner self not merely through a psychology, but through the identification of social and cultural factors which shape how the components of the inner life are intricate in the project of being human in the world (McBeath and Webb, 2002, p. 1021).

There is no escaping that the 'work' of social work is rooted in the tradition of a humanist morality that requires compassion for the other and benevolence, that is to 
say a genuine desire to be the best that one can be in the service of others. Those who do not have this other-centred motivation will forever struggle in a human service profession such as social work. Furthermore, it is in practical action, or praxis, that the 'work' of the social worker best manifests itself and inevitably such action takes place in the realm of uncertainty and unpredictability. Thus, 'doing the right thing' will always depend on the worker's ability to make the right judgements. As McBeath and Webb (2002) note, 'judgement itself has a moral character in that it requires mental effort, commitment to thinking, and consideration of the state of affairs obtaining. Morality under virtue ethics has an intellectual and motivational content that culminates in practical action ... The individuals' character is the stable reference point, not the action' (p. 1026). Thus, we see the pivotal 'use of self' and the connection of 'right judgement' to the critically reflective self knowledge that is so characteristic of Habermas’s emancipatory way of knowing.

Coming to know in an unbiased, just way is essential to good judgement which is always a process of weighing up possibilities and finding that golden mean, that all-things-considered point we inevitably reach. We strive not for perfectionism but for proportionism, for a balancing of universals or absolutes-those cherished social work values of acceptance, respect, self determination, and confidentialitywith the culturally contingent exigencies of the particular situations of which we are an intrinsic part; for that 'localized temporal moral sphere much closer to our lived experience’ (Wilks, 2005, p. 1260). As Houston (2003) notes, impartiality, or the balancing of needs and interests, is crucial in ethical judgement.

Herein, Habermas's communicative action and discourse ethics offer processes wherein virtues as 'generalizable capacities of self' (McBeath and Webb, 2002, p. 1026), ‘developed through moral interaction’ (Houston, 2003, p. 821), are 
conjoined with practical reasoning involving 'perception, judgement and flexibility' (McBeath and Webb, 2002, p. 1027) in both moral matters that are within our control and non-moral matters ‘which cannot be controlled fully’ (p. 1027). Social workers respond to the whole of what lies before them and do not parse out what's moral from what's not. Thus, as we have argued in this paper, Aristotle's 'broad conception of human flourishing' and his injunction that we must 'be the best we can be' for its own sake are intuitively what we humans understand to be a recipe for happiness. By implication, social workers want to do the best they can for their clients merely because this is what good social work practice is, regardless of rules, injunctions and the changing priorities of social service organizations. The constants are our valuesbased commitments to care for others and to respond to the call of human suffering. Every society needs its agents of compassion and, as long as social workers engage in practical action to relieve human distress, their tireless services will be needed.

The self reflective social worker using wise judgement is not a solitary player and virtue is not a characteristic understood only by solipsistic individuals. Virtue emerges 'from self-conscious analytical processes (such as critical self reflection) rooted in dialogical exchanges between committed inquirers' (Houston, 2003, p. 819). In fact, Habermas reminds us that virtues and ethical norms are practical and discursive, that is, they arise from and guide intersubjective communication towards cooperative action. All too often, social work training courses focus only on the practice skills of listening and communication when the real art inheres in deliberative skills which are often completely overlooked. The heuristic process of interaction between the worker and client is one of exploration and discovery-searching for the right solution-within a socio-cultural context. The norms which shape their interaction are already given within the context or the agency in which their 
intersubjective encounter takes place. Solutions are shaped by the worker and client in a dialogical engagement within a socio-cultural context in which norms of appropriate deliberation and communicative action have already been established, including the norms of the worker's professional culture. Nevertheless, Habermas reminds us not only that these norms must be constantly negotiated to achieve a common understanding and to establish the grounds for cooperative or communicative action but must also include compassion, regard 'and considerateness for the other'

(Houston, 2003, p. 821). Without such 'empathy it is doubtful whether moral development—or virtue_can flourish' (p. 822) within any culture. Thus we must establish these norms through practice-through dialogue properly regulated by Habermas's principles of 'inclusivity, open communication, empathy, and impartiality' (Houston, 2003, p. 823). In this way, over time, we institutionalise a moral culture through our dialogical engagements and our daily deliberations wherein virtue ethics and proportionism provide a midway between rule bound, deontological, codes and audits of ethics, on the one hand, and overly empirical, teleological, pragmatism, on the other.

\section{Conclusion}

This paper suggests a link between the philosophical underpinnings of central Aristotelian, Thomist and Habermasian propositions in strengthening the claims of proportionism as an approach to ethical and moral thought. Assumptions lying behind and impelling the direction of our argument include first, that an age that may be described as 'moderately post-scientific' demands more sophisticated methodology in dealing with matters of morality than is to be found in either the deontological or 
teleological approaches characteristic of the past 40 years or so; secondly, that a proportionism resting on the conjoined forces of Aristotelian, Thomist and Habermasian epistemologies has capacity to address the complex forms of plurality to be found in this 'moderately post-scientific' world; thirdly, that the same proportionism has capacity to identify and elicit a common thread to be found between the ancient, medieval and contemporary world; and, fourthly, that this common thread has potential to inform social work ethics in ways that can both strengthen its claims to universal values while being responsive to local cultural contexts.

\section{References}

Al-Ghazzali, A. 1991 The book of religious learnings. New Delhi: Islamic Book Services.

Aquinas, T. (1936) Summa theologica. (tr. L. Shapcote) London: Burns and Oates.

Aristotle, (1985) Nicomachean ethics. (tr. T. Irwin) Indianapolis: Hackett.

Augustine (1972) City of God. Harmondsworth, UK: Penguin.

Borthwick, C. (1995) Persistent vegetative state: A syndrome in search of a name, or a judgement in search of a syndrome? Monash Bioethics Review, 14(2): 20-26. 
Bruening, W., Brock, M., Schellhause, E. (1997) Educating the ethics committee. Journal of Nursing Staff Development, 13(5): 255-259.

Chambon, A., Irving, A. and Epstein, L. (eds). (1999) Reading Foucault for social workers. New York: Columbia University Press.

Doukas, D. and Berg, J. (2001) The family covenant and genetic testing. American Journal of Bioethics, 1(3): 2-10.

Flyvberg, B. (1998) Habermas and Foucault: Thinkers for civil society? The British Journal of Sociology, 49(2): 210-233.

Gray, M. (2005) Dilemmas of international social work: Paradoxical processes in indigenisation, imperialism and universalism, International Journal of Social Welfare, 14(2): 230-237.

Gray, M. and Fook, J. (2004) The quest for a universal social work: Some issues and implications, Social Work Education, 23(5): 625-644.

Gray, M. and Lovat, T. (2006) The shaky high moral ground of postmodernist ethics. Social Work/Maatskaplike Werk, 42(3/4): 201-212.

Gray, M., Coates, J. and Yellow Bird, M. (eds). (forthcoming) Indigenous social work around the world: Towards culturally relevant education and practice. Aldershot, Hants: Ashgate. 
Gray and Powell (forthcoming) The art of engagement: Rediscovering meaning in professional life. Chicago: Lyceum.

Habermas, J. (1972) Knowledge and human interests._(tr. J. Shapiro) London: Heinemann.

Habermas, J. (1974) Theorv and practice. (tr. J. Viertal) London: Heinemann.

Habermas, J. (1984). Theory of communicative action. vol 1, Boston: Beacon Press.

Habermas, J. (1987) Theory of communicative action. vol 2, Boston: Beacon Press.

Habermas, J. (2002) Religion and rationality: Essays on reason, God, and modernity. Cambridge: Polity Press.

Houston, S. (2003) Establishing virtue in social work: A response to McBeath and Webb. British Journal of Social Work, 33(6): 819-824.

Hughes, J.C. and Baldwin, C. (2006)). Ethical issues in dementia care: Making difficult decisions. London: Jessica Kingsley Publishers.

Hugman, R. (2005) New approaches in ethics for the caring professions. Basingstoke, Hampshire: Palgrave MacMillan. 
Ife, J. (2000) Local and global practice: Relocating social work as a human rights profession in the new global order. European Journal of Social Work, 4(1): 515.

Kolbian, A. and Shepherd, L. (2003) Narrative portrayals of genes and human flourishing. American Journal of Bioethics, 3(4): 15-22.

Koppelman, E. (2003) The dead donor rule and the concept of death: Severing the ties that bind them. American Journal of Bioethics, 3(1): 1-9.

Lovat, T. (1991) Main streams of bioethical thought. In W. Walters (ed.). Human reproduction: Current and future ethical issues. London: Bailliere Tindall. 511-528.

Lovat, T. (2003) The contribution of proportionism to bioethical deliberation in a moderately post-scientific age. Theology@ McAuley, 3 http://www.mcauley.acu.edu.au/theology/Issue3/index.html

Lovat, T. (2004) Aristotelian ethics and Habermasian critical theory: A conjoined force for proportionism in ethical discourse and Roman Catholic moral theology. Australian E-Journal of Theology, 3 http://dlibrary.acu.edu.au/research/theology/ejournal/aejt_3/Lovat.htm

Martin, G. (2005) Millenium dawn: The philosophy of planetary crisis and human liberation. London: GTM. 
McBeath, G. and Webb, S.A. (2002) Virtue ethics and social work: Being lucky, realistic, and not doing one's duty. British Journal of Social Work, 32(8): 1015-1036.

Miller, F. and Brody, H. (2002) What makes placebo-controlled trials unethical? American Journal of Bioethics, 2(2): 3-9.

Mitchell, K. and Lovat, T. (1993) Permanently unconscious patients and the ethical controversies surrounding artificial nutrition and hydration: Getting the facts straight. Linacre Quarterly, 60(1): 75-90.

Mitchell, K., Kerridge, I. and Lovat, T. (1993) Medical futility, treatment withdrawal and the persistent vegetative state. Journal of Medical Ethics, 19(1): 71-76.

Mitchell, K. Kerridge, I. and Lovat, T. (1996) Bioethics and clinical ethics for health care professionals. Sydney: Social Science Press.

Moreno, J. (1991) Institutional ethics committees: Proceed with caution. Maryland Law Review, 50(3): 895-903

Myser, C. (2003) Differences from somewhere: The normativity of whiteness in bioethics in the United States. American Journal of Bioethics, 3(2): 1-12. 
Parsi, K. and Egan, E. (2002) Patents: The public interest versus the private privilege. American Journal of Bioethics, 2(3): 45-46.

Parton, N. (2000) Some thoughts on the relationship between theory and practice in and for social work. British Journal of Social Work, 30(4): 449-463.

Plato (1987) The republic. (tr. D. Lee) Harmondsworth: Penguin.

Plato (1989) Protagoras. (tr. C. Taylor) Oxford: Clarendon.

Rawls, J. (1971) A theorv of justice. Cambridge, MASS.: Harvard University Press.

Reamer, F. (2001) The social work ethics audit: A risk management tool. Washington, D.C.: NASW Press.

Robert, J. and Bayliss, F. (2003) Crossing species boundaries. American Journal of Bioethics, 3(3): 1-13.

Robertson, J. (2001) Preconception gender selection. American Journal of Bioethics, 1(1): 2-9.

Sauer, M. (2003) Providing fertility care to HIV-1 serodiscordant couples: It's time to re-examine healthcare policy. American Journal of Bioethics, 3(1): 33-40.

Urmson, J. (1988) Aristotle’s ethics. Oxford: Blackwell. 
Varela, F. (1992) Ethical know-how. Stanford: Stanford University Press.

Waldron, E. (1992) Ethics committees, decision-making quality assurance, and conflict resolution. The Journal of Clinical Ethics, 3(4): 290-291.

Wendler, D. and Shah, S. (2003) Should children decide whether they are enrolled in non-beneficial research? American Journal of Bioethics, 3(4): 1-8.

Wilks, T. (2005) Social work and narrative ethics. British Journal of Social Work, 35(8), 1249-1264.

Witkin, S.L. and Harrison, W.D. (2001) Whose evidence and for what purpose. Social Work, 46(4): 293-296.

Wolf S. (1991) Ethics committees and due process: Nesting rights in a community of caring. Maryland Law Review, 50(3): 798-858.

Zoloth, L. (2002) Jordan's banks: A view from the first years of human embryonic stem cell research. American Journal of Bioethics, 2(1): 3-11. 